УДК 727.7:7

ББК 85.03

DOI:10.18688/aa155-8-91

Natalia Shalina

\title{
Defining Museums of Contemporary Art: the Phenomenon of Their Popularity in Recent Decades
}

More than 80 years has passed since the Museum of Modern Art in New York opened its doors to the public. Established in 1929 MoMA celebrated the emergence of a museum of a new type, a Museum of Modern Art, which has been spreading across the globe ever since. In the last few decades we have witnessed a boom in museums and centres of modern and contemporary art. Every capital city these days has a museum of this sort and they are continuing to spread across smaller cities. This process can be illustrated on the example of Austria: there are four museums of contemporary art in four major cities: Vienna (MUMOK, established 2001), Graz (Kunsthaus Graz, 2003), Linz (Lentos Art Museum, 2003) and Salzburg (Museum der Moderne, 2004). It has to be noticed that the population of the country is 8.2 million, while average population of the three last cities is $181,000^{1}$. All the museums are being promoted on major touristic websites and are described as "spectacular architectural landmarks"2. All of them are highly recommended for a visit.

This fact raises a number of questions, such as why museums of contemporary art have become so popular. Why do non-capital cities need them? What are the functions of such museums for their community? It is clear that capital cities are to represent history, art and culture of the entire country and that is why they have to have museums of contemporary art, as well as museums of classical art or ethnographic museums. However, smaller cities usually tend to have museums of a more focused sort, celebrating lives of famous personalities, presenting industries or crafts. Therefore the phenomenon of this rapid spreading of museums of contemporary art leads us to the question of their nature and meaning for their visitors.

Museums of contemporary art have become something more than just museums in common understanding of the term: places for entertainment, sharing and exchanging ideas, interaction - all what we can describe by the word agora or forum, in many ways as it used to be understood in ancient Greece and Rome [2, p. 8]. That happened partially for socio-economic reasons, but mostly because museums of contemporary art deal with living artists and art which happens now, so it is possible to provide the immediate dialogue between an artist and a visitor, overpassing years of distance in case of classical art and contemporary viewer.

\footnotetext{
10 Great Things To Do In Nice. Time Out. Available at: http://www.timeout.com/nice/ features/356/10-great-things-to-do-in-nice (Accessed August 3, 2014) Lynch H. Mapping Interpretation Practices in Contemporary Art, A report for engage Scotland.
2006. Available at: http://www.scottisharts.org.uk/resources/publications/research/pdf/RES22\%20Engage\%20Scotland\%20final\%20report.pdf (Accessed August 9, 2014)
} 
Museum professionals often complain that museums these days have become more similar to department stores, rather than classic museum institutions and they definitely get the point. What was predicted by Rosalind Krauss has occurred. Back in 1990 in "The Cultural Logic of the Late Capitalist Museum" she said: "It does not stretch the imagination too much to realise that this industrialised museum will have much more in common with other industrialised areas of leisure - Disneyland say - than it will with the older, preindustrial museum"3 [12]. Throughout the last decade museums of contemporary art have become new must-see places for tourists. In every guide book or tourist website one can find them among top-10 places to go almost everywhere across the globe. This has led to the fact that the number of visitors increased rapidly over the last 10 years, but not necessarily all the visitors would have had any interest in contemporary art.

We have to admit that this tendency seems logical in terms of the development of the postmodernist society and there even might be a positive side in this similarity between a museum and a department store, although the advantages of this process might be more obvious for museum visitors, rather than for museum professionals.

The aim of this research is to understand what a museum of contemporary art is and what makes it different from other art museums; to outline characteristic features of such museums; understand how they are seen by their visitors, and to reveal some positive and negative aspects from the position of visitors. This research is based on a survey of more than 100 participants, in which respondents were questioned about their interest towards contemporary art and experience of visiting various museums of contemporary art across the globe.

Certainly, today's museums are quite different to those institutions that appeared and spread during the Age of Enlightenment. We can hardly compare and find similarities between the Ashmolean, which was the first museum to be opened to public, with the Guggenheim museum in Bilbao, for example. As Eilean Hooper-Greenhill stresses "at a time when all other social fields are in a period of rapid change $\langle\ldots\rangle$, the lack of a flexible model for museums leads to severe problems in accommodating and working with the new elements that are imposed upon the existing field" $[9$, p. 8]. She says that museums have to work out new ways of being museums, elaborate this ability to adapt and find new possibilities for recruiting support. However, there is always a possibility of going too far, so at the same time while adhering to the principles of flexibility, museums have to preserve their authenticity, those features that make them museums, rather than department stores. But what are they?

This question has always been in the core of museum studies and many researchers tried to find a proper answer on it $[9$, p. 8]. One of the most recent studies "What, if Anything, Is a Museum?" by E. Dillenburg, brings together four different definitions of the term "museum", and picks out six features that, in his opinion, are typical for all museums. They are:

Non-profit;

Permanent;

Open to the public;

3 Kiasma. Lonely planet. Available at: http://www.lonelyplanet.com/finland/helsinki/sights/museums-galleries/kiasma (Accessed August 3, 2014) 
Public service (including aesthetics, enjoyment, and education);

Collections (covering acquisition, preservation and research);

Exhibits (embracing communication and interpretation) [7, p. 9].

E. Dillenburg finds all those points descriptive, but not dispositive. He stresses that none of them is unique for museums (except the last one), but each also works for other institutions, such as schools and hospitals. Trying to prove this he then tries to deconstruct all the definitions, although his arguments in some cases are not persuasive enough.

Indeed, some of the points are quite arguable and do not work for all museums, as for example, the principle of non-proficiency in case of privately funded museums is quite an issue; but as the most recent study based on contemporary institutions shows, this list makes perfect sense and works for the majority of museums, including museums of contemporary art. In this study we will apply these criteria to museums of contemporary art and try to point out characteristics that are specific for them.

Non-profit. E. Dillenburg stresses that for various legal reasons, museum professional organisations only admit non-profit members. Indeed, the majority of museums of contemporary art state their non-profit status, even if they are privately funded. However, from the side of public, this status does not really matter. To illustrate this, we can refer to the survey results: 5 out of 107 respondents said their favourite museum of contemporary art was Saatchi gallery. We can see that the certain level of confusion between museums and galleries takes place, especially in case of big galleries as Saatchi. This answer illustrates the fact precisely, and also shows that visitors do not mind status of institutions if they can get the same experience. To avoid this sort of confusions further on, we can stress the difference between museums and galleries on the galleries' basic definite profit nature (or the possibility of acquiring artworks) and their different approach to learning.

At the same time, from the side of museum professionals, commercial gallery professionals and researchers, the non-profit status does make a difference and as soon as most of the museums of contemporary art tend to stress their non-profit status in their mission statement we are more likely to define such museums as non-profit institutions.

Permanent. E. Dillenburg refers to Paul Martin from the Science Museum of Minnesota, who compares museums with a business, which could and has failed [7, p. 9]. Like every business, museums are set up on a permanent basis, with no difference whether they are run by government or private donors, but no one knows what may happen in a few years. Exactly this happened to the MoCA in Los Angeles, which was established in 1979 as the defining museum of contemporary art $^{4}$, and which developed one of the nation's most renowned permanent collections in a remarkably short time (numbering over 6,800 works by 2013). In 2013 after several years of economic struggle, it was merged with LACMA (Los Angeles County Museum of Art) and now operates as a part of it, but still under the MoCA name [10].

Besides, museums can move to other buildings, specifically constructed for them. This has happened a lot especially with museums of contemporary art that are to fit new image of today's cosmopolis, like the Astrup Fearnley Museum of Modern Art in Oslo.

\footnotetext{
4 Must-See London For Visitors. Time Out. Available at: http://www.timeout.com/london/attractions/must-see-london-for-visitors (Accessed August 3, 2014)
} 
As we see, permanent nature of museums is quite an arguable question and since a number of museums of contemporary art were only set up (or moved to other sites) within the last decade, we cannot talk about their constancy as we cannot predict their future. So this research will rely on examples that have been established since MoMA (1929), not depending on what basis they were set up on, exist now and occupy their own space, either a building specifically constructed for them or a loft.

Open to public. This point is quite clear; since the Ashmolean in Oxford opened its doors to public back in 1683, all the museums have tended to be open and easy accessible and treated their visitors with respect. Nowadays mission statements of museums of contemporary art are to emphasise this fact.

Public service. Serving the public has been museums' responsibility for centuries. In recent decades public services have taken on even greater importance, as museums recognised their need for attendance and public funding. Education these days is the primary way of serving public. This was set up by MoMA, which appeared 86 years ago with a mission to "encourage an ever-deeper understanding and enjoyment of modern and contemporary art by the diverse local, national, and international audiences that it serves" [1]. MoMA was the pioneer museum of modern art, which had been founded specifically as an educational institution, and since that time providing various opportunities for learning has become the priority for every museum of contemporary art. E. Hooper-Greenhill stresses that today the educational role of museums is claimed as a major justification, whereas knowledge is understood as a commodity that museums offer [9].

Collections. As C. Bishop stresses "without a permanent collection, it is hard for a museum to stake any meaningful claim to an engagement with the past, but also, with the future" [4, p. 24]. Museums of contemporary art tend to engage their visitors more with the present, rather than the past or the future; they live in a momentum and tell stories of our life in contemporaneity as does contemporary art. One might not agree with that, giving an example of Museums of Modern Art that, according to the title, are to represent the stories of modernism, which has already finished so can be formally referred to the past. And this would be a very good notion, however at the same time, we have to admit that this terminological confusion still takes place today and if theoretically we can draw a line between modern and contemporary, actually museums do not tend to do so, but combine both under the same roof. And again, in theory we can say that museums should have permanent collections, according to all the existing definitions of the word museum [7, p. 9], but in practice a lot of institutions do not have them and are still called museums and do museum work. There is an interesting example of Museum Moderner Kunst (MUMOK) in Vienna, which possesses a collection of modern and contemporary art and these days it consists of around 10,000 works ${ }^{5}$, but the collection is not represented on a permanent basis; there are only temporary exhibits that change once in a few months. Moreover, the experience of a visit has shown that even members of staff are unaware of the fact.

The New Museum of Contemporary Art in New York is another example of understanding collecting in such institutions [9]. If contemporary art is what was made within last ten years, then the collection should be renewed quite often to prevent the works from losing their con-

\footnotetext{
5 Museum of Contemporary Art in Los Angeles. 24 p. Available at: http://www.moca.org/museum/ us_home.php (Accessed July 28, 2014)
} 
temporary status. However, if a museum only represents the contemporary art of this sort, then the question is: what to do with the works that date back further than ten years?

We see that the question of having a collection is another problem in defining a museum of contemporary art: it partly overlaps the problem of its permanent nature and it definitely requires a separate in-depth study. By now we can clarify this point by stressing that in most cases museums of contemporary art have their own collections of art and they usually combine the permanent display with temporary exhibitions, but at the same time there is a huge number of museums that operate on the basis of temporary exhibition and still conduct a research and publishing work.

Exhibits. E. Dillenburg argues that exhibits are the only defining feature of the museum, because only exhibits make them different from other public service organisations. We definitely take this point and can conclude this brief investigation with a rough definition of a museum of contemporary art: it is a non-profit institution, which specialises in exhibiting modern/ contemporary art, occupies its own space and its main priority is serving public through providing opportunities for learning. The majority of museums of contemporary art hold a collection, but they also can operate on the basis of temporary exhibitions.

If compare to other contemporary museums, we can see that apart from exhibiting contemporary art, museums of contemporary art are not really different; all museums serve their public and offer various educational programmes and this lies in the core of their mission; basically every museum has its own permanent collection as well as provides temporary exhibits; all of them state their non-profit status and finally, there are lots of examples of great architectural projects made for museums (e.g. Natural History Museum in London). However, as one of my British colleagues said: "When I heard about your research on museums of contemporary art, I caught myself thinking that I actually go to Tate Modern more often than to Tate Britain. I am still wondering why and cannot find a proper answer".

According to statistics, the number of visits to Tate Modern has always been significantly higher than to Tate Britain. For example, in 2013 the overall number of the first site visitors 3,5 times exceeded the number of the second and since the beginning of this year this proportion has changed up to almost 6 times more for Tate Modern [15]. The survey also showed that out of $22,5 \%$ of respondents based in London, absolute majority of $80 \%$ said they visit Tate Modern more often than Tate Britain. This fact is just an illustration of popularity of museums of contemporary art comparing to museums of other kind. Certainly, the British Museum beats Tate Modern with a number of 6.6 million visitors ( 4.9 million in Tate) in 2013, as well as more people visit Louvre than the Pompidou Centre ( 8.3 to 3.3 million in $2012^{6}$ ), but for the recently appeared institutions, their popularity remains a fact.

According to the survey, respondents tend to stress three main features that could distinguish museums of contemporary art from other museums:

The nature of art represented.

Interactive displays.

Specific architecture.

gust 22, 2014)

MUMOK Collection. Available at: https://www.mumok.at/en/mumok-collection (Accessed Au- 
These are characteristics that we can define as art, interaction (additional learning facilities) and space, and they are to be discussed below.

Contemporary Art and the significance of interpretation

Modern and contemporary art is a complicated topic to reflect on, it differs considerably from our approach to classical art, for which dozens of art historians have elaborated a logical historical narrative. Contemporary art deals with nowadays issues, does not accept generalisations and requires some sort of personal engagement and response from a viewer; it comes alive with the viewer. As one of the respondents said: "Even if I don't understand the pieces, most times they are interesting enough to trigger conversation and debate".

According to the survey, more than $1 / 2$ of respondents said that they like contemporary art, but sometimes find it hard to understand. The percentage of those, who undoubtedly loved it, was significantly lower and hardly reached $20 \%$.

The problem of perception and understanding art appeared with the demise of figurative art and development of abstract art. The question of interpretation has become relevant since first cubist works by Picasso and Braque. E. Hooper-Greenhill refers to the theory of epistemes when describing how perception of art changed from classical to modern; and according to the modern episteme, "things are no longer simple visual pieces to be moved about on a board of one-level hierarchies, but are understood as organic structures, with a variety of different levels of complexity, and a variety of different relationships to each other, some at one level and some at another. The link between one organic structure and another one is no longer the identity of several parts, but the identity of the relationship between the parts, and of the functions which they perform" [9, p. 17]. This all can refer us further on to the theory of semantics and semiotics, but as a visitor, we probably would not want to go down that way.

Indeed, if in case of biblical, mythological or historical painting, visitors can refer to original texts, modern and contemporary artworks do not provide anything to refer to, apart from philosophical concepts. When the work of art does not clearly tell the story, the act of interpretation is needed and in this case it usually turns toward the analysis of its formal, material, technical or process-based aspects.

In asking what interpretation is and why it is needed we can rely on the study by Dr. Heather Lynch, held in 2006 and based on interviews and focus-groups. She defines the purpose of interpretation primarily as a vehicle to overcome perceived barriers to contemporary art, which are:

1. Arts culture, i.e. general public perceptions of contemporary art as elitist, inaccessible and irrelevant to most who are not directly involved in the arts (we can remind of the above-mentioned philosophy);

2. Lack of confidence and knowledge on the part of the viewer;

3. Poor media representation [13].

Other functions of interpretation are to widen participation and to increase the relevance of contemporary art to a diverse range of people.

Certainly, contemporary art might become a barrier itself; the meaning of works is often neither obvious nor was intended to be clear, and there is an expectation of effort on the part of the viewer. This statement can be proved by the survey results. Summing up the number 
of people, those said they either liked or quite liked contemporary art we have the absolute majority of $69 \%$ of all respondents. However, the answers to the question "if there is a choice between a museum of contemporary art and an art museum, where would you go?" shows that only $34 \%$ would rather see contemporary art, than classical art (66\%). This outcome is surprising, but then when comparing art museums to museums of contemporary art, the most common disadvantage of the latter was said to be the absence of their own history and their stories, "knowledge accumulated here".

Art museums are more "reverential", as another respondent said, and we cannot but accept this fact. They have already got their reputation by simply being storages for world famous masterpieces. Interpretation in art museums aims to expand existing knowledge about art by providing various forms of learning, while the main goal of interpretation in museums of contemporary art is to help their visitors make sense of contemporary art, to provoke the feeling of their involvement and participation.

Interpretation can take different forms. Following Dr. H. Lynch's research, we can stress main three:

Text (entrance panels, brochures, labels, etc.) as the simplest way to provide information. It gives one an opportunity to get as much information as he or she wants. Text can better explain the chosen mode of display, make the topic clear by providing various references to philosophical, sociological or any other concept.

Multi-literacy approach, which includes direct engagement with the artist and curator through talks, audio and video material, possible studio visits. This approach combines textual and non-textual methods.

Participatory (guided tours, panel discussions, workshops, etc.). This approach requires a mediator between an artist and a visitor.

A department of interpretation or at least interpretation team takes place in every museum these days, their work makes the process of meaning-making easier and more accessible for visitors. The main goal of interpretation in museums of contemporary art is to draw a parallel between art and reality, to find a personal response in every single person. In case of contemporary art, "the chief aim of interpretation is not instruction, but provocation" [5, p. 173], - stresses P. Carter-Birken, and this is exactly what educators and interpreters are trying to achieve - to provoke visitors' reaction by reading texts, looking at artworks, comparing them with other artworks, asking questions etc., so visitors then could make their own sense of what they just saw and apply this new knowledge to what is going on around them.

We can embrace the whole point of interpretation by words of Terry Barrett, who says that "if we interpret art with some self-reflection, we may get a glimpse into ourselves: what we value, what we prefer, what we resist, what we accept" [3].

Interactive displays and activities

Respondents often stressed that museums of contemporary art tend to be more interactive than art museums and other museums in general. To my mind, this consideration can be explained by three main reasons:

Using various approaches to interpretation and learning in museums of contemporary art, especially those that require a mediator (participatory form of interpretation); 
Using "interactives" , i.e. devices that visitors can operate individually. They include touch screens, audio stations, digital maps or even applications for visitor's smart-phones;

The nature of contemporary art itself: representation of artworks that naturally require an act of physical participation, as for example installations by Carsten Höller, or various performances where a visitor becomes an integral part of an artwork $^{8}$.

As we can notice, the third point is not related specifically to museum environment; we have to admit that more often installations and performances are represented in galleries and biennales of contemporary art. At the same time, it is worth noticing that interpretation of those artworks may vary depending on the space, where they are represented; in a gallery they are mostly separate pieces speaking from themselves, or they are brought together under the name of an artist or they illustrate a curator's concept. However, as soon as an installation or a performance comes to a museum space, they become a part of a complex exhibit, usually embracing a number of artists and themes and having an educational purpose first of all. One can say that some galleries can represent art with the same intention, offering various activities for schoolchildren and events for adults, as for example Saatchi gallery. The difference is that for museums education is the primary way of serving the public [7, p. 10], whereas for commercial galleries educational activities serve more as a vehicle for attracting people in order to achieve their primary purpose of selling art and getting profit.

However, the other two points do not make sense as specific features of museums of contemporary art - those are common for every museum. What makes it special here is a combination of subjective nature of contemporary art, which as mentioned requires a personal engagement, and interactive approach to interpretation from the side of museum educators. The use of interactives serve the same purpose of helping the process of interpretation as guided tours, panel discussions and workshops with the only distinction that it is a personalised experience as every visitor operate the devices individually.

Interactive displays emerged first in science centres, which was a logical consequence of practical orientation of science. In art museums they appeared much later and were to provide additional facts about artworks and artists. Nowadays interactive displays vary depending on their technological media and may include all sorts of things that the term "hands-on" activity can embrace; from try-on experience to drawing on touch-screens and using smart-phones. Mobile apps and other ways of using smart-phones are becoming more popular day by day. Interestingly, this sector has become a separate industry for some IT-companies, e.g. Heritage Interactive, which specialises on designing mobile apps specifically for museums ${ }^{9}$. Apart from apps, some museums use QR-codes and offer their visitors to look up information using their smart-phones.

However, the question of effectiveness of interactives remains controversial. Opposite to Science museums, interactives in museums of contemporary art do not illustrate the practicality of art by conducting an experiment, but just give a wider context of where the artwork was made, by whom and what media was used. Interactives offer visitors various paths for

$7 \quad$ The term used by Andrea Witcomb in Witcomb A. Reimagining the Museum: Beyond the Mausoleum. - London: Routledge, 2003. - 208 p.

$8 \quad$ E.g. Marina Abramovich show “The Artist Is Present” in MoMA in 2010.

9 Projects can be seen here: http://heritageinteractive.co.uk/portfolio (Accessed August 19, 2014). 
interpretation: by learning facts that may underlie the creation of artworks, by answering the questions that refer to visitors' personal experience, by creating a masterpiece on a screen, etc. However, those technological innovations can obviate the challenge many visitors enjoy in museums: working some things out for themselves ${ }^{10}$ [8]. Indeed, there are a number of concepts that deal with the question of whether art has more aesthetical or informative nature, but we have to admit that every artwork creates a visual image first of all and this image is to be seen by visitors primarily. As Tate educators stress, "everything they need to know is in the work"11 [1]. In this case the use of new technologies in museums of contemporary art is based on the common belief that this way of engaging visitors with art will make the museum experience "fun-filled" and "enlightening" at the same time and moreover, will create future audiences.

The other opinion stresses that use of interactives gives wider opportunity for engagement and learning. As soon as our lives today inseparably intertwined with digital technologies and we use them in almost every aspect of life, museums have to be updated and use technologies not only as a vehicle for attracting new audiences, but as a tool for active learning.

"What is happening at the moment is the Wild West - no one knows what the outcomes are going to be"12 [16] said Alex Morrison, managing director of digital consultancy Cogapp, commenting on growing popularity of mobile apps in museum environment. Indeed, the process of digitalisation of museum sphere is very new and the outcomes of it cannot be seen now. However, as most of innovations that did not have positive responses at the beginning, this one has great potential and high level of visitors' approval.

Museums of contemporary art as must-see places for tourists

Thomas Krens, the director of the Guggenheim Museum, has codified the successful $21^{\text {st }}$ century museum experience as "great collections, great architecture, a great special exhibition, a great second exhibition, two shopping opportunities, two eating opportunities, a high-tech interface via the Internet, and economies of scale via a global network" [6, p. 55]. This description entirely embraces all existing arguments about consumer nature of today's museums and their preference to serve public, rather than art or history they contain; this is exactly what Rosalind Krauss predicted back in 1990, when compared the new industrialised museum with Disneyland.

We have already agreed that it is not a collection that makes a museum of contemporary art, although we have seen that it is contemporary art that makes people come to museums and the curators, those do their best in terms of interpreting art and making people engaging with art. In this case T. Krens' definition is absolutely fair, but what about other points he made? Especially the "great architecture", which makes the third characteristic of a museum of contemporary art, stressed by respondents.

Since Frank Gehry designed his famous building for Guggenheim Museum in Bilbao in 1997, architecture of museums has become a separate area of architectural interest and research. As A. McClellan notices, the success of the Guggenheim was so big, that dozens of

\footnotetext{
$10 \quad$ History, The New Museum. Available at: http://www.newmuseum.org/history (Accessed July 11, 2014)

11 Austria population 2014. Available at: http://worldpopulationreview.com/countries/austria-population/ (Дата обращения)

12 Things To Do In Antwerp. Lonely planet. Available at: http://www.lonelyplanet.com/belgium/flanders/antwerp/things-to-do (Accessed August 3, 2014)
} 
other cities across the globe subsequently approached F. Gehry hoping to reproduce the "Bilbao effect"; the construction of the Guggenheim resulted in transforming the city's image completely, a faded industrial centre suddenly was reborn as a popular cultural destination, the number of visitors increased spectacularly, instead of the 450,000 visitors projected for the first year, over 1.3 million came, increasing the income up to $\$ 219$ million $^{13}[13$, p. 53].

Certainly, the architecture of museums became nearly as important as the art they contain and attracts visitors no less. Many significant architectural projects have come to life since Bilbao. They include museums of contemporary art in Europe, USA and Asia, encompassing new architectural projects along with reconstructions or extensions of existing ones. Their designs vary from Frank Gehry's evasive shapes and Santiago Calatrava's transforming and moveable projects to the so-called lofts, converted from warehouses and factories into contemporary architectural spaces. All those projects were intended to revoke their city areas by attracting public attention, tourist flow and subsequently new sources of possible funding.

However, after a decade "Bilbao effect" has led to a contradiction and now there are three main opinions on it: critics', public's and tourist industries'. Going back to comparing a museum with a department store, critics stick to the idea of traditional museum values that have to represent art well, rather than celebrate new fashionable space where this art is shown. Thus, a lot of researchers think that art simply got lost in the shuffle and the true purpose of the museum was betrayed [11]. J. Perl, for example, calls these museums "funhouses" and says that the process of their spreading leads to the annihilation of the museum as we know it [14, p. 31].

The critics would always insist on a museum as a setting for attentive viewing and refined conversation, governed by conventions and theories, whereas the public would need a socially engaged museum, embodying civic values in an impressive building that combines symbolism and accessibility ${ }^{14}[13$, p. 56]. This was stressed by A. McClellan with a notion of that insiders' and outsiders' points of view have never coincided. He illustrated this point by multiple examples of museums starting from the $18^{\text {th }}$ century.

Public's opinion shown by A. McClellan finds its proof in the words of Daniel Libeskind, the architect of The Michael Lee-Chin Crystal addition to the Royal Ontario Museum, Canada: "Architecture in our time is no longer an introvert's business. On the contrary, the creation of communicative, stunning and unexpected architecture signals a bold re-awakening of the civic life of the museum and the city"15. In addition to his words we can refer to the survey results.

Bearing in mind the idea of how architectural setting can affect visitor's impression, respondents were asked what they liked most about their experience of visiting museums of contemporary art, and not given any possible answers, such as "building" or "space". Of 74 people, who visited any of such museums across the globe, only 12 said they liked either of those variants. It seems not so much, but comparing to the number of answers "art"16, what

13 Mini key figures. Cultural Statistics 2012. 53 p. Available at: http://www.slideshare.net/peyregne/ cultural-statistics-in-france-key-figures-abstract-2012 (Accessed August 26, 2014)

${ }_{14} \quad$ Mini key figures. Cultural Statistics 2012. 56 p. Available at: http://www.slideshare.net/peyregne/ cultural-statistics-in-france-key-figures-abstract-2012 (Accessed August 26, 2014)

15 About MoMA. Available at: http://www.moma.org/about/ (Accessed August 21, 2014)

16 Other respondents either did not give any information apart from the name of the museum they visited, or said something else. 
difference does it make? From these number, we can assume that either the space was not significant or, what is more likely, they did not consider it as a separate entity, but as a complex.

Interestingly, some respondents mentioned the role of building, when comparing their experience of visiting a museum of contemporary art to other museums they visited. Thus, for one visitor, architecture turned out to be a negative experience in Tate Modern, while positive in the Natural History Museum (London) and the British Museum. Another one said that space is usually better organised and it is easier to navigate in museums of contemporary art, than in any classic museum, but at the same time they all look similar and make an impression of "inhuman 3-ds MAX" interiors. However, more often respondents were expressing positive opinions, stressing that "contemporary art museums often have exciting buildings, and are more experimental about space». Some museums were accessed as "good examples of a synthesis of contemporary architecture and art” like Kiasma (Helsinki) and MAMAC (Nice), which proves our assumption made earlier.

As we can see, visitors' opinions differ as well as their views on contemporary art; it would be more surprising if they were similar. And what is more important, comments were made mostly on particular examples of museums, rather than based on generalisations.

The third opinion on the problem of architecture of museums of contemporary art and their space belongs to representatives of tourist industry. Their position became important as an economic consequence of "Bilbao effect". When Bilbao and a number of cities changed their image of industrial urban areas after founding museums of contemporary art in them, they became new centres for culture and tourism, occupied a new significant market niche, which has constantly developed. Logically, tourism experts have another opinion on museums and this opinion is coming from the side of economic profit.

To prove this, a brief overview of most popular tourist websites was carried out. The searching request was "Top 10 things to do in ... <city>" and such sources as Lonely Planet, Time Out, Trip-advisor and The Guardian were chosen. The aim was to see from what perspective museums of contemporary art were represented. Certainly, this paper cannot embrace a robust research on the topic that is why the search was limited by choosing the cities that had been especially mentioned by respondents: London, Paris, Helsinki, Nice, Antwerp and Istanbul.

Lonely planet recommends its readers Kiasma in Helsinki as a symbol of the city's modernisation ${ }^{17}$, i.e. the significance of the building stands on the first place, whereas art goes second. Time Out Nice directly sends the tourists from the airport to museums and the first one recommended is Musée d'Art Moderne et d'Art Contemporain, whose large permanent collection features a good showing from the Nice School, New Realism and Pop Art ${ }^{18}$, so here it goes the other way round: art itself looks more important. Surprisingly, in case of Antwerp, Lonely planet featured another museum of contemporary art, not the one mentioned in the survey; the newly opened in 2011 MAS (Museum Aan de Stroom) [17], which is located in a spectacular 10-floor building, designed by architects Neutelings and Riedijk and serving

17 Kunsthaus Graz. Available at: http://www.museum-joanneum.at/en/kunsthaus-graz/architecture. html (Accessed August 22, 2014)

1810 Great Things To Do In Nice. Time Out. Available at: http://www.timeout.com/nice/ features/356/10-great-things-to-do-in-nice (Accessed August 3, 2014) 
as entertainment area (cafes, restaurants, shops, observation area on the top floor) as well as museum and galleries. MuHKA was not recommended by any of searching engines as well as Istanbul Modern.

Searches on London and Paris show Tate Modern and the Pompidou Centre from the same angle as Kiasma and MAS - architecture and space. Thus, the most significant feature of Tate Modern turns out to be the Turbine Hall and the spectacular outside view from the Millennium Bridge. The Pompidou Centre is introduced as today's one of the world's most famous pieces of modern architecture and is said to be housing the excellent Musée National d'Art Moderne as well as a cinema, library, shops and performance space ${ }^{19}$.

Summing up the data, we can notice an interesting fact that actually the sensation of architecture of museums of contemporary art has not been made by their visitors, but provoked by touristic industry. Comparing the survey results with websites overview we see that visitors rarely notice the architectural setting itself, more in complex with art exhibited; but on the Internet museums are promoted more as buildings worth seeing with entertaining facilities, rather than museums containing exciting contemporary art. Moreover, all those settings are usually emphasised and especially recommended to be visited as, for example, the gift shop in the Tate Modern, which is "excellent, and the perfect opportunity to pick up books and souvenirs that will gather admirers rather than dust" [14]. This is rather disappointing, but at the same time perfectly fits Thomas Krens' definition and makes absolute sense for market as nothing can make profit in a museum, but a café, a restaurant or a bookshop.

The reason for this tendency is quite obvious, since we have already mentioned that shift, which museums had done from serving art to serving public. J. Mastai in her research explains that that shift was caused by lack of government support and a turn to the development of sources of funding directly from the public, so logically, the strategies for maintaining the financial health of museums have switched to serving the visitors. Today museums of contemporary art raise funds through offering corporate sponsorship, foundation grants, admission fees at the door, and a variety of cost centres, ranging from cafés and shops to the rental of the museum for functions such as weddings, bar mitzvahs, and events hosted by corporations for their clients. So it has become the main permanent task for museums to attract the customers and gain their allegiance through membership, while ensuring that they spend as much money as possible each time they visit the museum. J. Mastai even ceases to use the term a visitor, by entitling her article "There Is No Such Thing as a Visitor", and changing it to a customer. There is a good generalisation about all museums of contemporary art, made by C. Bishop, when she says that the only thing that binds all museums of this kind together is less a concern for a collection, a history, a position, or a mission, but a sense that contemporaneity is being staged on the level of image: the new, the cool, the photogenic, the well-designed, the economically successful [4, p. 12].

Certainly, there is a lot more to talk about and we cannot cover all the arguments in this research, but concluding what was said above, we can say that architecture of museums of contemporary art have and will play a significant role in city planning. In case of newly con-

1915 Must-See Modern (\& Postmodern) Museum Designs. Web Urbanist. Available at: http://weburbanist.com/2009/01/12/creative-modern-and-postmodern-museum-designs/ (Accessed August 1, 2014) 
structed buildings they will always become new must-see places for tourists and places for social activities for locals; in case of lofts, they will attract visitors by preserving their original purity while telling contemporary stories. From the economic point of view, cities will get profit by becoming popular touristic destinations ${ }^{20}$, museums by attracting higher numbers of visitors and thus increasing their funds, visitors by enjoying better service and more opportunities. The main challenge for museums is to stick to the same values that make them museums, rather than department stores, developing new strategies for engaging with public and opportunities for learning, while showing contemporary art of a high quality.

"Our aim must be to generate a condition in which visitors can experience a sense of discovery in looking at particular paintings, sculptures or installations in a particular room at a particular moment, rather than find themselves standing on the conveyor belt of history" 21 $[15$, p. 44]. These are words by Nicholas Serota and, to my mind, they explain what makes people go to museums of contemporary art. Art that requires participation either on a mental or physical level, makes people engage with it and facilities for interpretation, provided by museums, help to relate art to personal experience of every visitor. Terry Barrett's opinion about art revealing our personalities [3], to my mind, is the exact reason why these institutions have become so widely popular these days. Not only they offer an entertaining and comfortable experience of visiting a must-see place, but teach visitors about themselves and pay their attention to what is going on around them.

"Museums do many things - provide their visitors relative safety, a sense of place, distractions from everything else, a place to meet their friends and make new ones, to buy, eat, and drink things, hear concerts and lectures, and to feel empowered as they recognise that museums are here for them and work on their behalf without regard to their age, race, ethnic origin, religion, or sexual identity" [6, p. 52]. These words by J. Cuno, the President and CEO of the J. Paul Getty Trust were confirmed by one of the respondents, who when asked about the experience of visiting museums said that Tate was a place where one could feel comfortable.

Title. Defining Museums of Contemporary Art: the Phenomenon of Their Popularity in Recent Decades.

Author. Natalia Shalina - M.A. student. University of Westminster, Regent Street, 309, W1B 2HW London, UK. nataliashalina@gmail.com

Abstract. The aim of this research is to understand what a museum of contemporary art is and what makes it different from other art museums. This research is an attempt to outline characteristic features of museums of contemporary art, which way they are understood by their visitors, and to reveal some positive and negative aspects from the position of visitors. The methodology used to achieve this goal was based on a survey, in which respondents were questioned about their interest towards contemporary art and their experience of visiting museums of contemporary art (geographical frames of the research included countries of EU and Latin America, Russia, USA and Japan). According to the results, people tended to stress three main features that distinguished museums of contemporary art from other museums. These features included contemporary art and its interpretation in museum space, interactive approach to learning and architecture of museum buildings. Every aspect was explored more in depth. Tight connection between high level of popularity of museums

20 The example of Bilbao and a few other small cities have shown how industrial centres have become domains of culture; along with financial management and tourism, culture has become a leading urban industry. ${ }_{21}$ Statistical data set: Museums and galleries monthly visits. Available at: https://www.gov.uk/government/statistical-data-sets/museums-and-galleries-monthly-visits. 55 p. (Accessed August 8, 2014). 
of contemporary art and the development of tourist industry through the two last decades was revealed. This correlation between cultural and economic spheres allows looking at museums of contemporary art at the angle of economic changes in society, and forms a basis for a further research.

Keywords: museum of contemporary art; museum of modern art; Bilbao effect; museum audience; interactivity in museum; museum space; museum architecture; contemporary museum architecture; Tate Modern; MOMA.

Название статьи. Музеи современного искусства: феномен популярности в последние десятилетия.

Сведения об авторе. Наталья Шалина - студент магистратуры. Университет Вестминстер, Риджент стрит, 309, Лондон, Соединенное Королевство, W1B 2HW. nataliashalina@gmail.com.

Аннотация. Статья посвящена осмыслению феномена популярности музеев современного искусства в последние два десятилетия. Основной задачей исследования является определение самого понятия музея современного искусства, а также его функций и оценка его роли для его аудитории. Статья основана на данных, полученных при опросе людей, посетивших тот или иной музей современного искусства (географические рамки опроса включали в себя страны Евросоюза, Латинской Америки, Россию, США, и Японию). На основании ответов респондентов были выявлены основные особенности музеев современного искусства, отличающие их от других музеев. К таковым относятся: характер экспонируемого искусства, интерактивный подход к экспонированию, особая архитектура здания/пространства музея. В процессе исследования каждый из выделенных признаков был рассмотрен более детально и проиллюстрирован на примере мнений критиков и участников опроса. Выявлена связь музеев современного искусства с активным развитием туристической индустрии за последние два десятилетия, что позволяет рассмотреть феномен их популярности с точки зрения экономических изменений.

Ключевые слова: музей современного искусства; эффект Бильбао; аудитория музея; аудитория музея современного искусства; интерактив в музее; архитектура музея; Тейт Модерн; МОМА.

\section{References}

1. Arriaga A.; Aguirre I. Concepts of Art Interpretation in Interviews with Educators from Tate Britain. 2013. Available at: http://onlinelibrary.wiley.com/doi/10.1111/j.1476-8070.2013.01740.x/pdf (Accessed August 10, 2014).

2. Barrett J. Museums and the Public Sphere. Oxford, Wiley-Blackwell Publ., 2012. 262 p.

3. Barrett T. Interpreting Art: Reflecting, Wondering, and Responding. Boston, McGraw-Hill Publ., 2013. 192 p.

4. $\quad$ Bishop C. Radical museology. London, Koenig Books Publ., 2013. 147 p.

5. Carter-Birken P. Interpretation and the Role of the Viewer in Museums of Modern and Contemporary Art. Curator, 2008, vol. 51, no. 2, April, pp. 171-178.

6. Cuno J. Whose muse?: Art museums and the public trust. Princeton, N.J, Woodstock, Princeton University Press Publ., 2004. 208 p.

7. Dillenburg E. What, if Anything, Is a Museum? Exhibitionist, 2011, vol. 30, Spring, pp. 8-13.

8. Earle W. Technology in museums - less is more! Available at: http://www.spiked-online.com/newsite/article/ technology_in_museums_less_is_more/14433\#.U_OZTPldWrF (Accessed August 19, 2014).

9. Hooper-Greenhill E. Museums and the Shaping of Knowledge. London, Routledge Publ., 1992. 244 p.

10. Knight C. LACMA: MOCA's new old suitor. Los Angeles Times, 2013. Available at: http://articles.latimes.com/2013/ mar/08/entertainment/la-et-cm-critics-notebook-moca-lacma-merger-20130307 (Accessed July 28, 2014).

11. Knight C. When the Museum Becomes an Event. Los Angeles Times, 2000. Available at: http://articles.latimes. com/2000/may/28/entertainment/ca-34852 (Accessed August 1, 2014).

12. Krauss R. The Cultural Logic of the Late Capitalist Museum. 1990. Available at: http://www.jstor.org/discover/10.2 307/778666? uid=3738032\&uid=2\&uid=4\&sid=21104081119021 (Accessed July 10, 2014).

13. McClellan A. The Art Museum: From Boullée to Bilbao. Berkeley, University of California Press Publ., 2008. 364 p.

14. Perl J. Welcome to the Funhouse: Tate Modern and the Crisis of the Museum. New Republic, 2000, June 19, pp. 30-36.

15. Serota N. Experience or interpretation: the dilemma of museums of modern art. London, Thames \& Hudson Publ., 2000. 64 p.

16. Stephens S. The growth of mobile apps. Available at: http://www.museumsassociation.org/museum-practice/ apps/15062010-apps-trends (Accessed August 19, 2014).

17. Witcomb A. Reimagining the Museum: Beyond the Mausoleum. London, Routledge Publ., 2003. 208 p. 